\title{
Vocational Schools Business Japanese Curriculum Reform and Integration Analysis
}

\author{
Wang Shanshan \\ Foreign Language Department \\ Jilin Business and Technology College \\ Changchun, China \\ 182076127@qq.com
}

\begin{abstract}
Following the financial crisis, how to train not only proficient in foreign languages, and familiar with Japanese business practices and to master certain skills to meet market demand, "applied", "compound" talent has become a priority in our foreign language teaching workers engaged another major issue before us. This paper tries to Business Japanese professional orientation as a starting point, from the integration of theory and professional manpower Business Japanese Training Course, through the curriculum, teaching status of environmental resources Construction Discussion and Analysis of Reform Measures proposed to achieve training objectives of the new ideas. "Business Japanese" curriculum integration is a longterm, dynamic development process, our goal is to make better use of existing resources, to the culture, the purpose of improving students' ability to use the Japanese business. Vocational colleges should be further explored in future teaching practice and improve curriculum, better support business Japanese professional training objectives, to serve the local economic development.
\end{abstract}

Keywords-Business Japanese; curriculum integration; teaching mode

Business Japanese professional vocational institutions have different from the traditional Japanese specialty, which focuses on the ability of students to higher vocational colleges and Japanese language and business combination. In recent years, colleges and universities continue enrollment, continue to make the most in high school yet to develop good habits of independent study students vocational skills directly accept higher education, they lack perseverance in learning, memory emphasis on lack of knowledge of the language class repeated familiar memorize perseverance. Therefore, to develop students' interest in learning the language of higher vocational colleges, but also to equip them with considerable international trade theory knowledge and practical ability, is a serious problem in today's Vocational Business Japanese emerging specialty construction had faced[1]. Reasonably setting Vocational Business Japanese courses in basic Japanese and reform the traditional teaching mode, and how to make basic Japanese courses in high school and vocational high grade business Japanese courses match cultivate useful to adapt to the needs of society, as business Japanese Teaching who is currently trying to explore the issue. In this paper, a preliminary study on the set integration and reform teaching mode among Vocational Business Japanese courses.

\section{SETUP AND ORIENTATION OF HighER VOCATIONAL Business JAPANESE COURSE STRUCTURE}

Higher Business Japanese culture should be positioned to have a solid basic skills in Japanese, have strong listening, speaking, reading, writing and translation capabilities, and can handle Japanese Japanese-funded enterprises and foreign trade administration, etc., can skillfully use Japanese foreign trade transactions processing documents, business documents and daily translation work. As students enter vocational colleges out of high school to learn Japanese, learning must start from the foundation, but also must learn the system of international trade knowledge. Therefore, low-grade stage should focus on two parallel lines, both to give students lay the foundation of the Japanese, but also set the appropriate course of international trade, so that they understand the business, the process of international import and export, and to expand the students' knowledge surface[2].

\section{REFORM OF ClAssRoOM TEACHING CONTENT}

Since entering the Higher Colleges students studying in high school, or both for the Japanese economic and trade related knowledge and haven't been learning system, so the teacher will set up professional training programs were worried for a limited class of students can't grasp the needs and must knowledge prepared, easy to set up all kinds of knowledge are courses which hopes to increase class, course content relates to the breadth and depth, the more students will help[3]. But doing just the opposite, in violation of the law of vocational education, increase the burden of student learning, therefore, must be reformed to start from the following aspects:

\section{A. Integrated curriculum}

For business vocational colleges, Japanese professional curriculum should be based on the actual integration, Some appropriate repeat courses combined, Training Course will teach unity.

\section{1) Basic courses}

Many students choose when you enroll at a Japanese or Business Japanese, only relying on the Japanese comic book or favorite Japanese songs in childhood or in adulthood learned Japanese products in developed countries like Japan and the information made but the Japanese did not think Chinese people are known as "laughing inside, crying out," saying, 
because the Japanese pronunciation, although simple, but mixed with kana, kanji, ending, end of the sentence syntax change very much, these feature allows students to study for some time after the loss of confidence, resulting in a tired mood. For this, in some settings on the basis of Japanese course, can the original basis of the traditional Japanese and Japanese intensive courses to comprehensive programs for vocational students, and to reform the traditional teaching methods, just blindly on a blackboard writing on the blackboard teaching grammar, listening to all kinds, training sessions into the classroom boring grammar lesson teaching them, using modern multimedia teaching, enhance student interest in learning.

\section{2) Listening, speaking training courses}

On the basis of the traditional method colleges usually teach Japanese to listening, speaking and audiovisual said courses were provided separately from training and I hope that the students in listening, speaking aspect can be strengthened and improved. In the curriculum in higher vocational colleges, on the one hand due to the limited hours, listening, speaking and audio-visual programs, said separate opening, often only open two hours a week, fewer opportunities for training; a single training also make students feel fatigue. For example, in listening class which, since the course requires students to the attention of highly concentrated, useful search words, try to figure out the meaning of the original Japanese, the general students' attention will be gradually dispersed after half an hour, we can't be in two hours within We have reached one hundred percent focused hearing. On the other hand, the curriculum more, final exam and test subjects also increased, all subject classroom learning and exam covers the content is not convergence, so that students feel at a loss[4]. As we will be listening, speaking and audio visual and other training courses integrated into a unified "Listening and Speaking" class, uniform textbooks and courseware, sound, like a combination to achieve obtained from visual and auditory stimulation, thereby promoting among the hearing session, the session enhanced hearing in comprehensive training among Japanese students improve the level of practical application.

3) International Business courses and Japanese language courses combine

As students enter college from high school, the "poor white" basis to master certain knowledge of Japanese language and business, this teacher is also a big challenge. In the curriculum, low-grade stage, to lay the Japanese base, the Chinese should be taught courses in international trade practice, to avoid blindly emphasis on Japanese trade and ignore, because international trade curriculum itself will involve a lot of expertise, teachers students are not systematic understanding of the case directly with the Japanese to teach the students is quite laborious; in the high school stage, and gradually the Japanese language and business courses integrate open trade Japanese, business Japanese audio - visual, business Japanese Readings press digest, business Japanese business correspondence and other practical courses. I see a lot as some schools offer financial and other fancy Japanese but deep secluded courses that allow students actually difficult to learn but after graduation they rarely use immediately in the community, wasting hours of choreography in the investigation.
In addition, the setting of each course should be carefully considered, practical courses should generally be open 48 hours or more, so that students have enough time to learn the course[5].

\section{B. Reform the content and teaching methods}

Business Japanese majors overall quality and ability, fundamentally speaking, is to develop a culture of quality, culture is a cross-cultural communicative competence, rather than pure language training or communication skills. The language barrier is the biggest obstacle to exchanges between the two peoples, but the light is not enough to understand the language, but also understand the customs of other countries in order to exchange more smoothly. So for Business Japanese majors, not only to learn the Japanese language and business knowledge, but also to understand Japanese history, culture, traditions, customs, lifestyle, business etiquette and even the details of life, etc. can be more conducive to future employment. Students in the learning process of cultural and language input mainly rely on textbooks, and classroom teachers to teach Japanese. Therefore, the Business Japanese in these areas have put forward new demands.

\section{1) Changes in classroom teaching means}

Classroom teaching them to change the past, mainly to teachers in the teaching of teaching methods, to avoid "chalk and talk", as teacher preparation must be fully developed forms of teaching methods, the use of interactive teaching, such as core subjects institutions in general will set "Intensive Japanese "it covers a very wide range, it can be said to contain the listening, speaking, reading, writing and translation of the five courses. But the "Japanese Intensive" course is not the grammar class, don't too much emphasis on grammar, otherwise it will lead students in practical use excessively "cautious" and said nothing to encourage students to speak Japanese, first asked teachers to lead by example and create Japanese atmosphere. While the actual design of a variety of scenarios for students to practice according to the text content of tissue binding, such as teaching materials when it comes to "interview" scene, in explaining the relevant text grammar structure the future, Japanese companies can be properly designed human resources personnel interview candidates scene, the scene of such organizations comply with the session, allowing students to deepen the impression and grasp the practical application method.

2) The use of modern technology to improve students' Japanese level[6].

Classroom teaching methods focus on improving flexibility, Active use of modern teaching methods, teaching courseware promotion. The use of advanced modern teaching methods, multimedia teaching intuitive, vivid teaching methods, a week for students to see the Japanese TV movie or Japan, enable students to understand Japanese customs, habits; via the Internet allows students to collect the latest information-rich learning content, a mastery of Japanese new developments.

3) Practice teaching in schools and enterprises to build

Specific method is to use "going out, please come in." "Going out" and that is more Japanese-funded enterprises, Sino-Japanese joint venture foreign trade companies and well- 
known entrepreneur in contact with each other to communicate information to understand the characteristics of each industry. Once a year or two workshops on Japanese personnel training mode, inviting local Personnel Bureau leadership, Japanese companies as well as senior figures in excellent general manager of foreign trade companies come to the school to discuss and research. Maintain sufficient amount of information to students to create more opportunities for students to use as a holiday to Japanese-funded enterprises, Sino-Japanese joint ventures and foreign trade companies to visit internships, organize students to participate in various activities Japanese translators translate, test their Japanese level in practice.

Teachers should provide the necessary conditions for student learning within the classroom and outside the classroom, so that students' intercultural communicative competence has been further improved. Teachers not only to combine materials in the classroom setting profiles intercultural knowledge introduction, guide students to compare differences in the Japanese mode of thinking in the teaching, so that students' cognitive, understand the cultural differences, a conscious reference to the right to communicate cultural background. In the extra-curricular, teachers should also be multi-channel culture nutrient intake to maximize the creation of good Japanese culture, reading and communication process more attention to cultural details which, for a deeper understanding of the cultural factors behind the language, referring to the content of textbooks, allow students to participate in theater performances and simulation scenarios sessions, organized students to watch Japanese movies, TV series, for students through sensory contact with Japanese culture information and mind to a relaxed mood to experience Japanese culture and perception of their culture, especially business occasions on interpersonal skills, understanding of the nature and content of the Sino-Japanese cultural differences, so that in future business activities appropriately, gracefully crosscultural communication.

4) Focus on combining research and business knowledge of Japanese

Currently there are three Japanese grade examination about: International Japanese Language Proficiency Test, J-TEST Business Japanese Proficiency Test and the University of Japanese professional four or eight exams, including international organizations long history of Japanese Language Proficiency Test, a wide range of people in the industry are esteem, and become Japanese companies hiring staff and went to Japan to study the basis; and J-TEST business Japanese Proficiency test is currently only set up the test center in Shanghai and Dalian, a relatively small staff sit; college major Japanese four TEM organization since 2002 Since the exam, since time is short and the organization is limited to college students can sit, still not been accepted by the industry, therefore, through the international Japanese Language Proficiency test level 2 or level 1 , as a measure of a student majoring in Japanese levels standards, assessment of new recruits for employers preferred conditions of employees. In the process of teaching Business Japanese usual among senior students to master how to make a set of text vocabulary, grammar, listening and reading level to achieve Grading standards, and that they can on Japanese business to a new level, I believe that this There is no contradiction. In the basic course the process to lay the basis for the Japanese students, promote the improvement of its Japanese business level, we can create some minor courses to enhance the ability to guide students' examination Grading and speaking ability training as business Japanese courses and supplementary training.

\section{Hinder Higher COLLEGES Business JAPANESE TEACHING REFORM FACTORS}

\section{A. Must Strengthen Business Japanese "double" Faculty}

Currently Vocational College of Business Japanese professional teachers more structure for university teachers majoring in Japanese, but the Japanese both a solid foundation and a wealth of business experience in actual combat, capable of low-grade to high school curriculum integrated curriculum of business Japanese teachers are very less. When it comes to the business part of the program, the Japanese professional teachers are often first to spend a lot of effort to identify the meaning and practical significance of Chinese business information in order to accurately explain to the students. Therefore, creating a "double teacher" teaching team became the Higher Colleges of Business Japanese Specialty Construction and Development of urgent tasks.

\section{1) Strengthen the internal construction of teachers}

Strengthening Japanese teacher of Japanese language and culture is very important accomplishment. Japanese professional teachers to in-depth and detailed understanding of the history, culture, traditions, customs, way of life and even the details of life in Japan, and correctly handle the relationship between language teaching and culture teaching. Japanese professional teachers must have a wealth of knowledge, the understanding of Japanese society, culture, economy, current events and other changes. But also on the Chinese and Japanese cultures at the same time we have a more profound understanding, but also well at helping students improve crosscultural communication awareness and communication process to avoid the misuse of cultural phenomenon. After school hours for students supplementary reading some magazines, newspapers, novels, these books are mostly new, interesting, and life, easy to accept students. Magazine and newspaper articles to cover all aspects of politics, economy, culture, science, the degree of difficulty of the article should be appropriate, so that students can understand and appreciate the content of the article, based on the Japanese vocabulary political, economic and cultural aspects also we continue to expand.

2) The introduction of the teacher has a wealth of business experience

Many Japanese teacher colleges are mostly graduates from universities, schools believe they solid foundation of knowledge, there is potential. Sources of Teachers from school to school, and from the few companies to recruit, even from the company recruitment, the candidates must be born Japanese professional background, even if the student candidates are very experienced, if not majors in college will be turned away. I believe that this method of recruitment hinder a lot of work 
experience to the Japanese people to join the ranks of teachers. Japanese companies asking for is experienced, professional and strong talent, if you want to the students to learn the knowledge and companies closer, it must be for those who have business experience professors teachers, because only they know the company needs What kind of people with personal experience to teach, will be more to enhance the students' actual combat, to equip students with company needs specialized knowledge as soon as possible, companies will be more willing to recruit these highly specialized graduates, rather than only emphasizes recruitment of work experience. Those who have never experienced corporate life of a teacher, but also should go to the company as interns and receive training company, put their training into both Japanese solid foundation, but also practical experience of practical teacher. These two ways to enrich the sources of teachers, strengthening of teachers, more importantly, and the students trained more in line with the needs of society.

\section{B. Strengthen the teaching business Japanese Textbooks}

Applicable to vocational domestic business is the lack of Japanese language teaching materials, from 2004 related survey shows that the Japanese textbook publishing business such as "Japanese business negotiation," "International Business Japanese Conversation" and a total of only 20 kinds, after that have been published related to business Japanese textbooks, some universities also try to develop from the ground up to the senior business development in Japanese textbooks, but the slow development of publishing, such as "basic business Japanese" textbook published only twelve, no

Follow-up materials. At the same time are common following questions: (1) There is no systematic and progressive teaching grammar contains practical tips and business Japanese textbooks; (2) Variety of bibliographic messy, teaching materials and design and the number of hours of teaching does not actually dovetail, it is difficult task of teaching competence; (3) Lack of authority can support the entire three-year vocational teaching business Japanese teaching process. Therefore, in order to guide classroom teaching and promote students' self-learning ability to develop relatively sound and practical business Japanese textbooks it has become an urgent need. Must rely on Japanese experts, excellent teachers and all students return to the university's translation, and edit more suitable for business Japanese language teaching materials.

\section{To strengthen the vocational teaching practice \\ achievement Business Japanese research and development}

Research on Japanese teaching and learning in the country relative to other non-universal languages is in a relatively high level, but precisely because many Japanese university teachers are mostly university graduates, on the Japanese emphasis on grammar or a Study course, so that guide business Japanese Teaching relatively small number of papers. Accordingly, in the Business Japanese vocational education teachers should also be strengthened in the usual research and reflect on the various aspects of teaching, strengthen its cultivation, the usual sort of teaching practical results of research and development, to explore vocational Business Japanese professional development. Business Japanese teaching purpose is to enable students to master business Japanese business Japanese language and use to communicate, successful business communication in addition to a good knowledge of the Japanese language and essential business knowledge, implicit Japanese national cultural background knowledge in Japanese language also can't be ignored. Today our Japanese language education is in a stage of rapid development, Business Japanese Teaching should adhere to the "people-oriented" approach, give full play to each teacher's enthusiasm and creativity to maximize mining and mobilize students' learning potential, and constantly improve and perfect business Japanese students' intercultural communicative competence, so that students find joy in learning, find the confidence to create favorable conditions for employment and future development of students.

\section{CONCLUSION}

"Business Japanese" curriculum integration is a long-term, dynamic development process, our goal is to make better use of existing resources, to the culture, the purpose of improving students' ability to use the Japanese business. Vocational colleges should be further explored in future teaching practice and improve curriculum, better support business Japanese professional training objectives, to serve the local economic development.

\section{REFERENCES}

[1] Zhao Y. Application and Research on Curriculum Reform System of Theory and Practice-based Integration[J]. Guide of Science \& Education, 2012.

[2] Tanaka T. The topic of curriculum reform: focusing on the integration of subjects: A sociological examination of the differentiation and integration of subjects (IV. Sessions on selected topics)[J]. Japanese Journal of Educational Research, 1997, 64(5):80-83.

[3] Lan-Ying L U. Requirements Analysis on Higher Vocational Business English Curriculum Reform[J]. Journal of Taizhou Polytechnic Institute, 2007.

[4] Ying-Shan L I. Constructing the "School-Enterprise Integration" Administration Management Specialty Curriculum System at Higher Vocational Colleges[J]. Journal of Hebei Tourism Vocational College, 2014.

[5] Han Yu. Analysis on Modern Transformation of Technology Ethics Education Model of Japanese Advanced Vocational Schools[J]. Vocational and Technical Education, 2015.

[6] Peng Shipu. The Inner Construction of Vocational Schools must Choose the Path of School-enterprise Cooperation, Work-study Integration, and Teaching-learning-doing Integration[J]. Journal of Shaanxi Youth Vocational College, 2015. 